\title{
A nemzetbiztonság veszélyeztetésének előfordulása a magyar migrációs jogszabályokban
}

\author{
Manifestations of Threats to National Security \\ in the Hungarian Migration Legislation
}

\begin{abstract}
A biztonságpolitikában és a nemzetbiztonsági közösségben több elnevezés is létezik a nemzetbiztonság veszélyeztetésére, ilyenek többek között: az új kihívások, a nemzetbiztonsági kockázatok, a nemzetbiztonság veszélyeztetése, a fenyegetések. A tanulmány kísérletet tesz annak bemutatására, hogy a magyar migrációs jogszabályokban milyen szakkifejezések szerepelnek. A tanulmány felhívja a figyelmet arra, hogy a nemzetbiztonság fenyegetésének vannak fokozatai, amelyet a szakmai kifejezésekben is célszerü követni.
\end{abstract}

Kulcsszavak: nemzetbiztonság, veszélyeztetés, kihívások, kockázatok, fenyegetések, skála

There are several terms in the security studies and in the intelligence community for endangering national security, such as: new challenges, national security risks, endangering national security, threats. The study attempts to present the technical terms used in Hungarian migration legislation. The study draws attention to the fact that there are levels of threat to national security that should be followed in professional terminology as well.

Keywords: national security, migration, risks, threats, scale

Tanársegéd, PhD, Nemzeti Közszolgálati Egyetem, Terrorelhárítási Tanszék. E-mail: laufer.balazs@uni-nke.hu, ORCID: 0000-0002-5877-7694 


\section{Bevezetés}

A tanulmányban azt vizsgálom, hogy a magyar migrációs jogszabályokban miként jelenik meg a nemzetbiztonság veszélyeztetése. Célom annak bemutatása, hogy sokszor eltérő kifejezések és fokozatok fordulnak elő, ugyanakkor jelentésüket nem határozták meg pontosan.

A nemzetbiztonság veszélyeztetettsége súlyossági fokozatok szerint kategorizálható. Ilyen kategóriák ismertek a biztonság- és védelempolitikában, de a minősített adatok védelme is egyfajta fokozatosságra épül. Ez a kategorizálás hiányzik a nemzetbiztonsági ellenőrzéseknél és a nemzetbiztonsági célú migrációs ellenőrzéseknél is, bár utóbbi területen érzékelhető különbségtétel a kockázat, súlyos veszély, nemzetbiztonsági érdek sérelme és egyéb, a veszélyeztetést jelentő kifejezések megfogalmazásában.

A rendészet egyik alaptézise: a rendészeti jog a közjogba tartozik. A rendészet tényleges szervei a közigazgatás, ezen belül főleg az államigazgatás intézményrendszerének képezik részét. A közigazgatás egyik és a többi feladattól markánsan elválasztható ága a rendészeti feladatok ellátása. ${ }^{2}$ Az Alaptörvény 46. cikk alapján a rendészet alapvetően két ágra bontható:

a) a rendőrség(ek) alapvető feladataira (a búncselekmények megakadályozása, felderítése, a közbiztonság, a közrend és az államhatár rendjének védelme, a jogellenes bevándorlás megakadályozása), ${ }^{3}$

b) nemzetbiztonsági rendészeti feladatokra (Magyarország függetlenségének és törvényes rendjének védelme, nemzetbiztonsági érdekeinek érvényesítése), ${ }^{4}$ amelyeket a nemzetbiztonsági szolgálatok látnak el. ${ }^{5}$

Szervezeti oldalról a rendészet magában foglalja a rendőrségeket, a Nemzeti Adóés Vámhivatalt (NAV), a büntetés-végrehajtást (bv. szervek), a nemzetbiztonsági szolgálatokat és a katasztrófavédelmi szervezeteket (polgári védelem, tűzoltóság). ${ }^{6}$ A polgári nemzetbiztonsági rendészet szervei: az Információs Hivatal, az Alkotmányvédelmi Hivatal, a Terrorelhárítási Információs és Elemző Központ (TIBEK), továbbá a Nemzetbiztonsági Szakszolgálat, ${ }^{7}$ ugyanakkor tevékenységi területét érintően szorosan idetartozik a terrorizmus és a terrorcselekmények mint nemzetbiztonsági kockázatok felderítéséért és megelőzéséért felelős Terrorelhárítási Központ (TEK), továbbá az állam biztonságos - befolyástól és korrupciótól mentes - múködését szavatoló Nemzeti Védelmi Szolgálat (NVSZ) is, bár utóbbi kettő nem nemzetbiztonsági szolgálat, hanem speciális rendeltetésű - különös hatáskörű - rendőrségek. A polgári

Balla Zoltán: A rendészet alapjai és egyes ágazatai. Budapest, Dialóg Campus, 2017. 27.

Alaptörvény 46. cikk (1).

Alaptörvény 46. cikk (3).

Balla (2017) i. m. 27.

Finszter Géza: Rendészettan. Budapest, Dialóg Campus, 2018. 156.

Balla (2017) i. m. 64.

A TEK nemzetbiztonsági célú, vagy nem bűnügyi célú titkos információgyűjtéséről lásd például Finszter (2018) i. m. 227. 
nemzetbiztonsági szolgálatok olyan rendvédelmi szervek, amelyek rendészeti igazgatási feladatokat korlátozott körben teljesítenek, ${ }^{9}$ másodlagos rendészeti szervek. ${ }^{10}$

\section{A nemzetbiztonság és az idegenjog}

A külföldiekkel kapcsolatos rendészeti feladatok három nagy csoportba sorolhatók: határrendészeti, idegenrendészeti és menekültügyi. ${ }^{11} \mathrm{Az}$ idegenrendészeti eljárás főszabályként akkor indul, amennyiben a külföldi személy megsérti a beutazás vagy a tartózkodás feltételeit. Az idegenrendészet fő terepe az irreguláris migráció kezelése, hatósági intézkedés lehetőségének megteremtése azokkal szemben, akik az ország területére jogellenesen érkeztek, és tartózkodásuk is az. Szintén az idegenrendészet foglalkozik azokkal, akik jogszerűen utaztak be, de tartózkodási joguk időközben megszűnt. ${ }^{12} \mathrm{Az}$ idegenrendészeti eljárás célja közvetlenül nem nemzetbiztonsági természetű. Egy illegálisan tartózkodó külföldi kiutasítása vagy kitoloncolása mögött általában a tartózkodásával összefüggő jogellenes állapot húzódik. ${ }^{13}$

Az idegenrendészet és a nemzetbiztonsági rendészet ugyanakkor egymást metsző halmazok. A nemzetbiztonsági kockázatot jelentő külföldiek mozgásának korlátozása, velük szemben kényszerintézkedések végrehajtása, kiutasításuk, kitoloncolásuk, azaz eltávolításuk az ország területéről idegenrendészeti eljárás keretében történik meg. Nemzetbiztonsági okokból beutazási és tartózkodási tilalom is elrendelhető. A szolgálatok törvényi felhatalmazás ${ }^{14}$ alapján kezdeményezhetnek idegenrendészeti kényszerintézkedéseket olyan külföldiekkel szemben, akik sértik az ország nemzetbiztonsági érdekeit. ${ }^{15}$

A nemzetbiztonsági érdekek veszélyeztetése vagy sérelme az idegenrendészeti jogszabályok mellett megjelenik a menedékjogi normák terén, továbbá az állampolgársági jogban is. A tanulmány arra vállalkozik, hogy a fokozatosságot is figyelembe véve bemutassa, a migrációs jog terén számos formában jelenik meg a nemzetbiztonság veszélyeztetése.

Finszter (2018) i. m. 268.

A másodlagos rendészeti szerveket csak az különbözteti meg az elsődleges rendészeti szervtől, hogy kevesebb, de erőteljes a legitim kényszerfellépési lehetőségük az általános rendőrséghez képest. Lásd: Balla Zoltán: A rendészet fogalma és rendszere, a nemzetbiztonsági igazgatás. In Korinek László (szerk.): Értekezések a rendészetről. Budapest, Nemzeti Közszolgálati Egyetem Rendészettudományi Kar, 2014. 37. Windt Szandra: Külföldiek rendészete, bevándorlás és menekültügy. In Korinek László (szerk.): Értekezések a rendészetről. Budapest, Nemzeti Közszolgálati Egyetem Rendészettudományi Kar, 2014. 297.

12 Hautzinger Zoltán: A nemzetbiztonsági érdek megjelenése a migrációban és az idegenjogban. In Dobák Imre - Hautzinger Zoltán (szerk.): Szakmaiság, szerénység, szorgalom. Ünnepi kötet a 65 éves Boda József tiszteletére. Budapest, Dialóg Campus, 2018. 271.

Hautzinger (2018) i. m. 273.

Lásd: Szmtv., Harmtv. vonatkozó pontjait alább.

Hautzinger (2018) i. m. 273. 


\subsection{A nemzetbiztonság veszélyeztetése a menedékjogi normákban}

A menedékjogról szóló 2007. évi LXXX. törvény (Met.) elemzése alapján látható, hogy a menekültkénti elismerést kizáró okok között szerepel a nemzetbiztonság veszélyeztetése. ${ }^{16} \mathrm{~A}$ hatályos törvényi szöveg szerint nem lehet oltalmazottként sem elismerni azt a külföldit, akinek az ország területén való tartózkodása a nemzetbiztonságot veszélyezteti. ${ }^{17}$

Ettől eltérően fogalmaz a törvény a menedékes kategória esetében: a Met. 21. § (1) b) szerint nem lehet menedékesként elismerni azt a külföldit, „akinek Magyarország területén való tartózkodása nemzetbiztonsági érdeket sért".

A menedékjogról szóló törvény végrehajtásáról szóló 301/2007. (XI. 9.) Korm. rendelet (Met. Vhr.) 2/A. § szerint a Kormány a Met. tv. III., VII-IX. fejezete szerinti eljárásokban annak megállapítása érdekében, hogy a tv. hatálya alá tartozó személynek „Magyarország területén való tartózkodása veszélyezteti-e a nemzetbiztonságot”, szakhatóságként az AH-t és a TEK-et jelöli ki.

Figyelmet érdemel, hogy a Met. szerint nem lehet menedékesként elismerni azt a külföldit, akinek a Magyarország területén való tartózkodása nemzetbiztonsági érdeket sért. A végrehajtási rendelet nem erre, hanem a nemzetbiztonság veszélyeztetésének vizsgálatára ad felhatalmazást a szakhatóságoknak.

A törvény 10. § (3) bekezdés a) pontja szerint „a menekült jogosult a jogszabályban meghatározott személyazonosító igazolványra és - ha nemzetbiztonsági vagy közrendi érdek a kiállítását nem zárja ki-Genfi Egyezményben foglalt kétnyelvú úti okmányra”. A 17. § (2) bekezdés szerint „az oltalmazott - a 10. § (3) bekezdés a) pontjától eltérően - a jogszabályban meghatározott úti okmányra jogosult. Az úti okmány kiállítása nemzetbiztonsági vagy közrendi érdekből megtagadható".

Előfordulhatnak olyan esetek, amikor a külföldi menekült vagy oltalmazott jogállása nem jelent nemzetbiztonsági kockázatot, és így nincs ok az elismerésének megtagadására vagy visszavonására, ugyanakkor nemzetbiztonsági érdekből nem célszerü, ha úti okmánnyal rendelkezik, és esetleg annak birtokában elhagyja az országot (például korábbi státusza felülvizsgálat alatt áll). ${ }^{18}$

A Met. alapján a menekültstátuszt kérelmező bizonyos esetekben menekültügyi őrizetbe vehető. A törvény 31/A. $\S(1)$ bekezdés d) pontja értelmében a külföldit a menekültügyi hatóság őrizetbe veheti, amennyiben „az elismerését kérő őrizetbe vétele a nemzetbiztonság vagy a közrend védelme érdekében szükséges".

A törvény 51 . § (7) bekezdés j) pontja szerint a menekültügyi eljárás során a kérelem gyorsított eljárásban is lefolytatható, többek között abban az esetben, amennyiben „a kérelmező súlyos okból veszélyt jelenthet Magyarország nemzetbiztonságára vagy

$16 \quad$ A Met. 8. § (4) szerint „nem lehet menekültként elismerni azt a külföldit, akinek Magyarország területén való tartózkodása a nemzetbiztonságot veszélyezteti”.

17 Korábban a törvény 8. § b), valamint a 15. § b) szerint nem lehetett menekültként, oltalmazottként elismerni azt a külföldit, akinek Magyarország területén való tartózkodása a nemzetbiztonságot sérti.

18 Menekültügyi ismeretek. Tansegédlet, Budapest, Országos Idegenrendészeti Főigazgatóság, 2019. augusztus. 91. 
közrendjére, vagy az idegenrendészeti hatóság a közbiztonság vagy a közrend sértése vagy veszélyeztetése miatt kiutasította".

\subsection{A nemzetbiztonság veszélyeztetésének kérdése a szabad mozgás és tartózkodás jogával rendelkezők viszonyait, valamint a harmadik országbeli állampolgárok beutazását és tartózkodását szabályozó normákban}

A szabad mozgás jogával rendelkezők körében nincs engedélyezésre irányuló eljárás, nincs formális nemzetbiztonsági szempontú ellenőrzés sem, ugyanakkor regisztrációs kötelezettség fennáll Magyarországon. ${ }^{19}$

A fenti körülmény ugyanakkor nyilvánvalóan nincs összefüggésben azzal a jelenséggel, hogy EGT-polgárok is jelenthetnek veszélyt: személyük, hátterük, kapcsolatrendszerük, törekvéseik. Az EU tagállamainak polgárai esetében általában nem beszélhetünk súlyos nemzetbiztonsági kockázatokról, de az elmúlt két évtized rávilágított, a nyugat-európai úgynevezett homegrown terrorizmus következtében a már EU-s állampolgárnak született, bevándorlói hátterű személyek tevékenysége is jelenthet kiemelt veszélyt.

A szabad mozgás és tartózkodás jogának korlátozása: a szabad mozgás és tartózkodás jogával rendelkező személyek beutazásáról és tartózkodásáról szóló 2007. évi I. törvény (Szmtv.) 33. § alapján „az e törvény hatálya alá tartozó személyek beutazáshoz és tartózkodáshoz való joga az arányosság elvének betartásával és az érintettnek kizárólag olyan személyes magatartása alapján korlátozható, amely valódi, közvetlen és súlyos veszélyt jelent a közrendre, a közbiztonságra, a nemzetbiztonságra vagy a közegészségügyre".

Itt a törvényalkotó a nemzetbiztonság veszélyeztetésének egy minősített esetét követeli meg ahhoz, hogy mozgásszabadsága és a tartózkodás joga korlátozható legyen; három minősítő jelző is nyomatékosítja ezt: 1. valódi, 2. közvetlen, 3. súlyos. Ezek közül az utóbbit még könnyebb definiálni, a jogalkalmazás során a szolgálatoknak értelmezni, de a veszély közvetlensége is már vitákat válthat ki egy külföldi személy tevékenységének megítélése során. A „valódi” jelző álláspontom szerint kevéssé értelmezhető, hiszen még a távoli veszély (ami a fent hivatkozott tanulmányok alapján inkább a kihívás kategóriájába eshet) is valódi, csak a bekövetkezés esélye és a várható kár mértéke elenyésző, vagy még térben, időben távoli.

Amennyiben a közvetlen és súlyos veszélyt az eljáró szerv kellő alappal vélelmezi, az ügyfél által bírósági úton megtámadott döntés során a bíró az elé tárt bizonyítékok, körülmények, jelentések alapján juthat eltérő következtetésre. Ennek során is - ahogyan az eljáró rendészeti szerveknek - figyelemmel kell lenniük az arányosság

19 Az Európai Unió léte a tőke, az áruk (és a szolgáltatások), valamint a személyek szabad áramlásán alapul. A személyek unión belüli szabad mozgáshoz és tartózkodáshoz való joga képezi az uniós polgárság alappillérét. Az EU-n belüli egyik fő vívmány az, hogy a tagállamok polgárai a közösség területén szabadon mozoghatnak és tartózkodhatnak. Lényegében az EU-tagállamok polgárai de facto csak bejelentési, regisztrációs kötelezettséggel bírnak, amikor más tagállamba költöznek, vagy huzamosabb ideig ott kívánnak tartózkodni. 
elvének betartására és arra is, hogy kizárólag a külföldi személyes magatartása válthat ki adminisztratív korlátozást.

A kiutasítás azt jelenti, hogy szabad mozgás és tartózkodás jogával rendelkezők az országból kiutasíthatók. A törvény 40. § (2) bekezdés c) pontja szerint „az eljáró idegenrendészeti hatóság kiutasíthatja azt az EGT-állampolgárt vagy azt a családtagot, akinek beutazása vagy tartózkodása valódi, közvetlen és súlyos veszélyt jelent Magyarország közrendjére, köz- vagy nemzetbiztonságára".

A vízumkonzultáció ezt jelenti: ${ }^{20}$ „Felhatalmazást kap az idegenrendészetért és menekültügyért felelős miniszter arra is, hogy a külpolitikáért felelős miniszterrel, a polgári nemzetbiztonsági szolgálatok irányításáért felelős miniszterrel, valamint a polgári hírszerzési tevékenység irányításáért felelős miniszterrel egyetértésben, rendeletben határozza meg azokat a harmadik országokat, amelyek állampolgárai részére kiadott vízumokról a Vízumkódex ${ }^{21} 31$. cikk (1) bekezdése szerint a központi vízumhatóság tájékoztatást kér".

Külön kategóriát jelent a tartózkodási kártyával, állandó tartózkodási kártyával rendelkezők köre. ${ }^{22}$ Rájuk is a fent jelzett Szmtv. 33. § az irányadó. Az OIF a szabad mozgás jogával rendelkező harmadik országbeli részére tartózkodási kártyát állít ki, amely visszavonható, vagy annak lejártát követően nem kerül hosszabbításra, amenynyiben a személy súlyos veszélyt jelent Magyarországra nézve, ehhez ugyanakkor az idegenrendészeti hatóság egyedi ügyben véleményt kérhet olyan hatóságtól, amely képes a szakkérdés megítélésére, így például terrorelhárítási szempontból a TEK-től vagy általános nemzetbiztonsági szempontból az AH-tól. Új szabályozás került bevezetésre a magyar állampolgárok harmadik országbeli családtagjai vonatkozásában. A magyar állampolgárok harmadik országbeli állampolgár családtagjaira vonatkozó eljárásokban, a 2019. január 1-jét követően indult és megismételt eljárásokban már a harmadik országbeli állampolgárok beutazásáról és tartózkodásáról szóló 2007. évi II. törvény (Harmtv.) rendelkezéseit kell alkalmazni. Ekkor lépett hatályba a szabad mozgás jogával rendelkezőkre vonatkozó törvény ezen módosítása. ${ }^{23} \mathrm{~A}$ fentiek alapján a Harmtv. letelepedési engedély kiadására vonatkozó szabályai szerint kell megkeresni a kijelölt szakhatóságokat szakhatósági állásfoglalás kérése céljából. ${ }^{24}$

$20 \quad$ Az Szmtv. 86. § (6)-(7) bekezdés alapján felhatalmazást kap az idegenrendészetért és menekültügyért felelős miniszter, hogy a külpolitikáért felelős miniszterrel, a polgári nemzetbiztonsági szolgálatok irányításáért felelős miniszterrel, valamint a polgári hírszerzési tevékenység irányításáért felelős miniszterrel egyetértésben rendeletben állapítsa meg azokat az eseteket, amikor - a közbiztonság és a nemzetbiztonság védelme érdekében - más schengeni állam vízumkiadó hatósága a kilencven napot meg nem haladó, tervezett tartózkodásra jogosító vízum kiadását megelőzően a központi vízumhatósággal egyeztet.

21 Az Európai Parlament és a Tanács 810/2009/EK rendelete (2009. július 13.) a Közösségi Vízumkódex létrehozásáról (Vízumkódex).

22 Létezik az úgynevezett magyar állampolgár családtagja tartózkodási kártya, amikor a magyar állampolgárt kísérő vagy magyar állampolgárhoz csatlakozó harmadik ország állampolgárságával rendelkező családtag kaphat tartózkodási kártyát. Az eljáró idegenrendészeti hatóság engedélyezheti annak a személynek a családtagként történő tartózkodását is, aki a magyar állampolgár eltartottja, vagy vele legalább egy éve egy háztartásban él, illetve akiről súlyos egészségügyi okból a magyar állampolgár személyesen gondoskodik. EGT-állampolgár családtagjának jogszerű magyarországi tartózkodását szintén tartózkodási kártya biztosítja. Bevezette az egyes migrációs tárgyú és kapcsolódó törvények módosításáról szóló 2018. évi CXXXIII. törvény. Szmtv. 94. § (3). 
A harmadik országbeli állampolgárok beutazásáról és tartózkodásáról szóló 2007. évi II. törvény (továbbiakban: Harmtv.) alapján a harmadik országbeli állampolgárok a nem magyar állampolgárok, valamint azok, akik nem az Európai Unió (EU) tagállamainak polgárai, azaz az EU-n kívüli államok polgárai. Pontosabb megfogalmazás szerint szabad mozgás jogával az Európai Gazdasági Térség ${ }^{25}$ állampolgára és családtagja, másfelől a magyar állampolgár magyar állampolgársággal nem rendelkező családtagja rendelkezik. Így harmadik országbeli állampolgár az, aki állampolgársága igazolására harmadik ország által kiállított érvényes úti okmányt használ fel, vagy nem valószínűsíti, hogy megilleti a szabad mozgás és tartózkodás joga. ${ }^{26}$

A kilencven napot meg nem haladó, tervezett tartózkodás során az a harmadik országbeli állampolgár, aki vállalaton belüli áthelyezés céljából az EU tagállama által kiadott érvényes tartózkodási engedéllyel és érvényes úti okmánnyal rendelkezik, és amennyiben a beutazása vagy tartózkodása Magyarország közrendjét, közbiztonságát vagy nemzetbiztonságát, illetve közegészségügyi érdekét nem sérti vagy veszélyezteti, jogosult az EU tagállamai területén szabadon mozogni, kilencven napot meg nem haladó, tervezett időtartamig Magyarországra beutazni és tartózkodni, a vállalaton belüli áthelyezés keretében munkát végezni.

A Harmtv. 9. § (1) bekezdés alapján „a közbiztonság és a nemzetbiztonság védelme, valamint a Vízumkódexben meghatározottak szerint a migrációs kockázatértékelés, a visszaélések és csalások megelőzése és kiszűrése érdekében meghatározott esetekben a kilencven napot meg nem haladó, tervezett tartózkodásra jogosító vízum csak a központi vízumhatóság hozzájárulásával adható ki”. ${ }^{27}$ A Harmtv. 111. § (6) bekezdése szerint „rendeletben állapítják meg azokat az eseteket, amikor - a közbiztonság és a nemzetbiztonság védelme, valamint a Vízumkódexben meghatározottak szerint a migrációs kockázatértékelés, a visszaélések és csalások megelőzése és kiszürése érdekében - a kilencven napot meg nem haladó, tervezett tartózkodásra jogosító vízum csak a központi vízumhatóság hozzájárulásával adható ki, és más schengeni állam vízumkiadó hatósága a kilencven napot meg nem haladó, tervezett tartózkodásra jogosító vízum kiadását megelőzően a központi vízumhatósággal egyeztet".

Részben a fenti felhatalmazás alapján kiadásra került a 29/2010. (V. 12.) IRMKüM-PTNM együttes rendelet (a továbbiakban: Együttes rendelet), amely a három hónapot meg nem haladó tartózkodásra jogosító vízum kiadását megelőző kötelező egyeztetés eseteiről szól. A tanulmány szempontjából az Együttes rendelet azért érdemel figyelmet, mivel a nemzetbiztonság védelmének általános fogalmán túl konkretizálja a veszélyeztető tényezőket, és ennek kapcsán a fentiektől eltérő új kifejezést is használ: „[A] konzuli tisztviselő a központi vízumhatóság hozzájárulását kéri, ha a harmadik országbeli állampolgár [...] más személyes körülményére tekintettel feltehető, hogy a vízumkérelmének elbírálása a közbiztonság és a nemzetbiztonság védelme, valamint

\footnotetext{
25 Az EU mind a 28 tagállama, továbbá Izland, Liechtenstein, Norvégia (mint nem EU-tagok, de Európai Gazdasági Térségről szóló megállapodásban részes más államok), továbbá külön szerződés alapján Svájc.

26 Hautzinger Zoltán: Szemelvények a migráció szabályozásáról. Pécs, AddAnn, 2016. 27-28.

27 A központi vízumhatóság a fenti, Harmtv. 9. § (1) bekezdésében meghatározott hozzájárulás megadása, valamint a TV. 111. § (6) bekezdés b) pontja szerinti egyeztetés során történő válaszadás előtt köteles a vízumkérelemről az AH és a TEK véleményét kérni.
} 
a Vízumkódexben meghatározottak szerint a migrációs kockázatértékelés, a visszaélések és csalások megelőzése és kiszürése érdekében különös körültekintést igényel." Itt jelenik meg először és egyedül a jogszabályokban a nemzetbiztonság sérelme kapcsán mint kategória az, hogy „(többek között) a nemzetbiztonság védelme érdekében különös körültekintést igényel". Az Együttes rendelet további egyedisége, hogy részletesen kibontva felsorolja, mi minősül különös körültekintést igénylő kérelemnek, definiálva, hogy a migrációs jellegü kockázatok mellett melyek a nemzetbiztonság sérelmének elemei. ${ }^{28}$ Ehhez nemzetbiztonsági szolgálatok és a terrorizmust elhárító szerv ilyen tartalmú információit is figyelembe kell venni. ${ }^{29}$

A kilencven napot meghaladó tartózkodás általános szabályai keretében a Harmtv. felsorolja, mely feltételek fennállása esetén utazhat be és tartózkodhat Magyarország területén harmadik országbeli személy. A törvény 13. § h) pontja alapján beutazása vagy tartózkodása nem veszélyezteti Magyarország közrendjét, közbiztonságát, nemzetbiztonságát vagy közegészségügyi érdekét.

A Harmtv. végrehajtási rendeletében (114/2007. [V. 24.] Korm. rendelet a harmadik országbeli állampolgárok beutazásáról és tartózkodásáról szóló 2007. évi II. törvény végrehajtásáról - a továbbiakban: Harmtv. Vhr.) az alábbiak találhatóak:

Nemzeti vízum: „a vízumkiadó hatóság a vízum iránti kérelemről a közbiztonság és a nemzetbiztonság védelme érdekében meghatározott esetekben az AH és a TEK véleményét kéri". ${ }^{30}$

Tartózkodásiengedély-kérelem: az OIF regionális igazgatósága „a tartózkodási engedély iránti kérelemről a közbiztonság és a nemzetbiztonság védelme érdekében meghatározott esetekben az AH, a TEK és a rendőrség véleményét kéri" ${ }^{31}$

28 A 29/2010. (V. 12.) IRM-KüM-PTNM együttes rendelet 1. § (2) „A vízumkérelem elbírálása a közbiztonság és a nemzetbiztonság védelme, valamint a Vízumkódexben meghatározottak szerint a migrációs kockázatértékelés, a visszaélések és csalások megelőzése és kiszűrése érdekében akkor igényel különös körültekintést, ha egy adott országból érkező vízumkérelmezők vagy a vízumkérelmezők meghatározott csoportja körében felmerül annak a megalapozott lehetősége, hogy olyan személy is vízumot kérelmezhet,

a) aki Magyarország szuverenitását, területi épségét, politikai, gazdasági, honvédelmi vagy más fontos nemzeti érdekét veszélyeztető tevékenységet fejtene ki,

b) aki Magyarország gazdasági, tudományos-technikai, pénzügyi biztonságát veszélyeztető tevékenységet folytatna,

c) akinek a tevékenysége összefüggésbe hozható szervezett bűnözői csoportokkal, kábítószer-kereskedelemmel, fegyverkereskedelemmel, embercsempészettel vagy emberkereskedelemmel,

d) akinek a valós szándéka terrorcselekmény vagy terrorizmus finanszírozása búncselekmény elkövetésére irányul,

e) akinek vízumkérelme alapján folytatott eljárás keretében a személyes meghallgatása alkalmával kormányzati döntéseket megalapozó, külföldi eredetű információk szerezhetőek meg,

f) aki közremúködik haditechnikai eszköz vagy szolgáltatás, illetve kettős felhasználású termék vagy nemzetközileg ellenőrzött termékek és technológiák jogellenes forgalmazásában,

g) aki a vízumkérelem megalapozása céljából hamis vagy hamisított dokumentumot csatolna, hamis adatot közölne vagy a kiadott vízumokmányt meghamisítaná,

h) aki a kérelmezett vízumot céljával ellentétes módon kívánja felhasználni, vagy

i) aki a vízumban foglalt tartózkodási időt meghaladóan tartózkodna Magyarország vagy más schengeni állam területén."

29. Együttes rendelet 2. §a).

30 Harmtv. Vhr. 39. § (1).

31 Harmtv. Vhr. 50. § (1). 
Tartózkodásiengedély-típusok esetében: az OIF a hallgatói mobilitási tartózkodási engedély kiállítását megtagadja, ha „a hallgató tartózkodása Magyarország közrendjét, közbiztonságát, nemzetbiztonságát vagy közegészségügyi érdekét veszélyezteti”. ${ }^{32}$

A kutatási célú tartózkodási engedély esetében az OIF a kutatói rövid távú mobilitási igazolás kiadása céljából tett értesítéssel szemben kifogást emel, ha a kutató (vagy családtagja) „tartózkodása Magyarország közrendjét, közbiztonságát, nemzetbiztonságát vagy közegészségügyi érdekét veszélyezteti". ${ }^{33}$ A hatóság a kutatói hosszú távú mobilitási tartózkodási engedély kiállítását megtagadja, vagy a már kiadott engedélyt visszavonja, ha a kutató tartózkodása Magyarország nemzetbiztonságát veszélyezteti. ${ }^{34}$ A hatóság a kutató családtagjának tartózkodási engedély iránti kérelmét elutasítja, ha a családtag tartózkodása Magyarország nemzetbiztonságát veszélyezteti. ${ }^{35}$

Letelepedés: a letelepedési engedély egy határozatlan idejű magyarországi tartózkodásra jogosító engedély, amellyel állandó lakcím és egyéb, hasonló jogok járnak, mint amelyekkel a magyar állampolgárok rendelkeznek. ${ }^{36}$ A letelepedés lényegében egy új haza, a befogadó ország, esetünkben Magyarország elfogadása tartós otthonként.

Nem kaphat ideiglenes, nemzeti vagy EK letelepedési engedélyt az a harmadik országbeli állampolgár, „akinek a letelepedése veszélyezteti Magyarország közbiztonságát vagy nemzetbiztonságát". ${ }^{37}$ A Harmtv. Vhr. 97. § (1) annak megállapítása kérdésében, hogy a kérelmező harmadik országbeli letelepedése veszélyezteti-e Magyarország nemzetbiztonságát, elsőfokon az AH-t és a TEK-et, másodfokon a polgári nemzetbiztonsági szolgálatok irányításáért felelős minisztert szakhatóságként jelölte ki.

Kiutasítás és önkéntes távozás: „....nem kell határidőt meghatározni, vagy az idegenrendészeti hatóság hetedik napnál korábbi napra is meghatározhatja, ha a harmadik országbeli állampolgár magyarországi tartózkodása veszélyezteti a közrendet, a közbiztonságot vagy a nemzetbiztonságot". ${ }^{38}$

Átszállítás az országon: a Harmtv. Vhr. 141. § (5) e) alapján a harmadik országbeli állampolgár Magyarország területén történő légi átszállításhoz történő hozzájárulását a Főigazgatóság (OIF) megtagadhatja, illetve visszavonhatja, ha „a harmadik országbeli állampolgár átszállítása veszélyezteti Magyarország nemzetbiztonságát vagy közbiztonságát, közegészségügyi érdekeit vagy nemzetközi kapcsolatait".

Az idegenrendészeti kiutasítás és a beutazási és tartózkodási tilalom: a Harmtv. 43. § (1) c) pontja szerint „az idegenrendészeti hatóság önálló beutazási és tartózkodási tilalmat rendel el azzal az ismeretlen helyen vagy külföldön tartózkodó harmadik országbeli állampolgárral szemben, akinek a beutazása és a tartózkodása a nemzetbiztonságot, a közbiztonságot vagy a közrendet sérti vagy veszélyezteti".

A Harmtv. 43. $§(2)$ d) pontjával az idegenrendészeti hatóság idegenrendészeti kiutasítást rendel el azzal a harmadik országbeli állampolgárral szemben, „akinek

Harmtv. 21/A. § (5) c).

Harmtv. 22/A. § (3) b).

Harmtv. 22/B. § (2) b) és a Harmtv. 22/B. § (4) b).

Harmtv. 22/B. § (7) c).

Wetzel Tamás: A bevándorlás kérdése Magyarországon. Budapest, Publikon, 2011.

Harmtv. 33. $\S(2)$ b).

Harmtv. 42. $\S(6) d)$. 
a beutazása és tartózkodása a nemzetbiztonságot, a közbiztonságot vagy a közrendet sérti vagy veszélyezteti".

„Az a harmadik országbeli állampolgár, aki bevándoroltként vagy letelepedettként tartózkodik Magyarország területén, bevándorolt vagy letelepedett harmadik országbeli állampolgárral házassági vagy családi életközösségben él, és tartózkodási engedéllyel rendelkezik, csak akkor utasítható ki, ha további tartózkodása a nemzetbiztonságot, a közbiztonságot vagy a közrendet súlyosan sérti”. ${ }^{39}$ A tanulmány szempontjából ez esetben nemcsak a súlyosan jelzó érdemel figyelmet, hanem a parancsoló „csak akkor" szófordulat is. Másként van ez az emberkereskedelem áldozatainál: az emberkereskedelem áldozatává vált harmadik országbeli állampolgárt a számára biztosított gondolkodási idő alatt csak akkor lehet kiutasítani, amennyiben az ország területén való tartózkodása a nemzetbiztonságot, a közbiztonságot vagy a közrendet sérti. ${ }^{40}$

Más EU-tagállamban jogszerűen tartózkodó kiutasítása Magyarországról: „az EU tagállama által kiadott, a tagállam területén tartózkodásra jogosító engedéllyel rendelkező harmadik országbeli állampolgár csak akkor utasítható ki, ha Magyarország területén történő tartózkodása a nemzetbiztonságot, a közbiztonságot vagy a közrendet sérti". 41

A Harmtv. 45/A. $\S(1)$ bekezdés a) pontja szerint, a 43. $\S(2)$ bekezdésében foglaltaktól eltérően, az idegenrendészeti hatóság nem utasítja ki azt a harmadik országbeli állampolgárt, akit az EU más tagállamának hatósága határozatával a nemzetbiztonság vagy a közbiztonság súlyos és tényleges megsértése vagy veszélyeztetése miatt utasított ki.

Az idegenrendészeti hatóság „beutazási és tartózkodási tilalmat rendelhet el a jogsértés jellegére és súlyára, a harmadik országbeli állampolgár személyes körülményeire, ismételt beutazásának és tartózkodásának a közrendre, a közbiztonságra vagy a nemzetbiztonságra jelentett veszélyére figyelemmel”. ${ }^{42}$

A Harmtv. 47. $\S(6)$ bekezdése szerint „a beutazási és tartózkodási tilalom legfeljebb tíz évre rendelhető el, ha a harmadik országbeli állampolgár tartózkodása Magyarország területén a közrendet, a közbiztonságot vagy a nemzetbiztonságot jelentősen veszélyeztetné". Figyelmet érdemel a jelentősen jelző, amely a jogszabályokban a nemzetbiztonság sérelme kapcsán nem, vagy ritkán szerepel, holott valójában a kifejezés megfelelően árnyalja és hangsúlyozza a károsodás potenciális mértékét („jelentős kár” kifejezés széles körben használt).

Kitoloncolás: a kitoloncolás lényegében a hatósági kísérettel végrehajtott kiutasítás. A visszairányítást vagy a kiutasítást „,hatósági kísérettel (kitoloncolás) kell végrehajtani, ha a külföldi kiutazásának ellenőrzése a nemzetbiztonság, nemzetközi szerződésben vállalt kötelezettség érvényesítése, illetve a közbiztonság vagy a közrend védelme érdekében szükséges". ${ }^{43}$

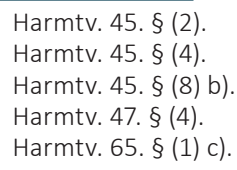


Hontalanság: a „hontalanság megállapítására irányuló kérelmet határozattal el kell utasítani, amennyiben a kérelmező tartózkodása sérti vagy veszélyezteti Magyarország nemzetbiztonságát". 44

A 2019. január 1-jétől hatályos törvényszöveg szerint „felhatalmazást kap a Kormány, hogy a jövedelemszerzési, munkavállalási vagy egyéb célú tartózkodási engedély jövőbeni benyújtását adott ország(ok) állampolgárai vonatkozásában rendeletben korlátozza, ha azok létszáma Magyarország számára közbiztonsági vagy nemzetbiztonsági kockázatot jelenthet" ${ }^{45}$ A felhatalmazás több szempontból is unikális: egyrészt tartalmában, hiszen egy-egy náció polgárainak számát korlátozza (külföldiek kvóták szerint), másrészt ezt az adminisztratív intézkedést közbiztonsági vagy nemzetbiztonsági okokból teheti meg. Különleges az is, hogy a migrációs tárgyú törvényekben itt jelenik meg egyedül a nemzetbiztonsági kockázat szakkifejezés, szófordulat.

\subsection{A nemzetbiztonság sérelmének megjelenése az állampolgársági jogban}

A honosítás a külföldiek nemzetbiztonsági ellenőrzésének egyik esete, amikor bizonyos feltételek fennállása esetén egy állam az idegenhonos személy részére biztosítja az állampolgárságot, azaz honosítja a személyt. A honosítás aktusával a kérelmező teljes, más állampolgárokkal azonos jogokkal és kötelezettségekkel rendelkezik.

A magyar állampolgárságról szóló 1993. évi LV. törvény (Áptv.) kimondja, hogy „kérelmére honosítható a nem magyar állampolgár, ha honosítása Magyarország közbiztonságát és nemzetbiztonságát nem sérti". ${ }^{46}$ Joggal merülhet fel a kérdés, a titkosszolgálatok világában mikor válik valami teljes bizonyossággá. Nagyon ritkán. A legtöbb esetben csak erősen valószínü, vagy majdnem biztos, a brit katonai skála szerinti almost certain (= majdnem biztos = 90\% felett) szintet érhetünk el egy információ többoldalú ellenőrzése által. ${ }^{47} \mathrm{~A}$ sérti kifejezés ez esetben jelentheti-e a veszélyeztetést is? Kérdés, hogy aki honosítás útján magyar állampolgár akar lenni, de személye a szolgálatok szerint valamilyen módon és mértékben veszélyezteti a nemzetbiztonságot (de „bekövetkezett” sérelmet nem okoz), annak esetében milyen (elutasító vagy észrevételt nem tevő) véleményt kap az állampolgársági ügyekben eljáró Budapest Főváros Kormányhivatala az Alkotmányvédelmi Hivataltól. Pontosítani lenne szükséges a törvényt a sértheti, illetve a sérti vagy veszélyezteti kifejezések beemelésével.

\footnotetext{
Harmtv. 78. §(1) c).

Harmtv. 111. § (1) c).

Áptv. 4. $\S(1) d$ ).

A szolgálatok és a tudomány világát összehasonlítva: utóbbi számára nincs sem időkorlát, sem elvi korlátja a bizonyításnak, míg a nemzetbiztonság szakterületén legtöbbször törvényi időkorlát (többnyire 90 vagy 60 nap, de egyes eljárásokban 30 vagy 20, sőt, akár 6-10 nap) és a közigazgatástól elvárt általános ügyintézési határidők (például 8 és 60 nap) jelentenek korlátot, és az „ügyfelek” is sok esetben olyan személyek, akik ezen szerepükről nem értesülhetnek.
} 


\section{Az Európai Unió (EU) két rendeletének elemzése}

Az uniós jog ez irányú elemzése se maradhat el. Az EU-s rendeletek és a határozatok kötelező erővel bírnak az EU egész területén, hatálybalépésük időpontjától kezdve. Két rendeletet célszerű a tanulmány szempontjai alapján elemezni: a Vízumkódexet, ${ }^{48}$ valamint az úgynevezett Schengeni határellenőrzési kódexet. ${ }^{49}$

\subsection{A Vízumkódex}

A Vízumkódex egyik alapvető célja, hogy a tagállamok közösen, egységesen és hatékonyan (és a fentiek érdekében együttmúködve) adják ki a vízumokat, elkerülendő, hogy az egyes tagállamok résekké váljanak az uniós pajzson. A Vízumkódex (18) bekezdése szerint „a helyi schengeni együttmüködés elengedhetetlen jelentőségű a közös vízumpolitika harmonizált alkalmazása és a migrációs és/vagy biztonsági kockázatok megfelelő értékelése szempontjából".

A 21. cikk (A beutazási feltételek ellenőrzése és kockázatértékelés) (1) bekezdése szerint „egységes vízum iránti kérelem vizsgálata során meg kell győződni arról, hogy a kérelmező eleget tesz-e a Schengeni határellenőrzési kódexben található beutazási feltételeknek, valamint különös figyelmet kell fordítani annak vizsgálatára, hogy a kérelmező nem jelent-e kockázatot az illegális bevándorlás vagy a tagállamok biztonsága tekintetében". 50

Bár a Vízumkódex eredetileg nem mondta ki, hogy a biztonság erősítése (is) a célja, de az egyik legfőbb eszköz az úgynevezett konzultációs mechanizmus, ${ }^{51}$ amikor a tagállamok megkövetelhetik, hogy más tagállamok központi hatóságai egyeztetést folytassanak az ő központi hatóságaikkal egyes harmadik országbeli állampolgárok vagy ilyen állampolgárok bizonyos kategóriái által benyújtott kérelmek vizsgálatakor. Az új szövegű 22. cikk már előtérbe helyezi a biztonság kérdéskörét. Az új 22. cikk szerint egy tagállam a közrend, a belsö biztonság, a nemzetközi kapcsolatok, illetve a közegészség veszélyeztetésére hivatkozva megkövetelheti, hogy más tagállamok központi hatóságai egyeztetést folytassanak az ő központi hatóságaival egyes harmadik

48 Az Európai Parlament és a Tanács 810/2009/EK rendelete (2009. július 13.) a Közösségi Vízumkódex létrehozásáról (Vízumkódex).

49 Az Európai Parlament és a Tanács (EU) 2016/399 rendelete (2016. március 9.) a személyek határátlépésére irányadó szabályok uniós kódexéről (Schengeni határellenőrzési kódex).

50 A 21. cikk (3) bekezdése alapján a konzulátus annak ellenőrzése során, hogy a kérelmező eleget tesz-e a beutazási feltételeknek, ellenőrzi többek között, hogy a kérelmezők a Schengeni határellenőrzési kódex definíciója szerint nem jelent-e veszélyt a tagállamok közrendjére, belső biztonságára, közegészségügyére vagy nemzetközi kapcsolataira, különösen nem áll-e a tagállamok nemzeti adatbázisai által ugyanezen okok miatt kiadott, beléptetési tilalmat elrendelő figyelmeztető jelzés hatálya alatt. A 32. cikk (A vízum kiadásának elutasítása) szerint a fent jelzett meghatározást kimerítő személy vízumkérelmét el kell utasítani. A XI. melléklet (amely az olimpiai és paralimpiai sportolók könnyített vízumeljárásait szabályozza) II. fejezet 3. cikk szerint kizárólag akkor állítható ki vízum, ha az érintett személy nem tekinthető egyik tagállam közrendjét, nemzetbiztonságát vagy nemzetközi kapcsolatait veszélyeztetőnek sem.

51 Az úgynevezett 22. cikk szerinti egyeztetés, hivatalos nevén az „Előzetes egyeztetés más tagállamok központi hatóságaival". 
országbeli állampolgárok vagy ilyen állampolgárok bizonyos kategóriái által benyújtott kérelmek vizsgálata során. ${ }^{52}$

\subsection{A határellenörzési kódex}

A kódex (6) bekezdés bevezető szakasza értelmében „a határellenőrzésnek elő kell segítenie az illegális bevándorlás és az emberkereskedelem elleni küzdelmet, és meg kell előznie a tagállamok belső biztonságát, közrendjét, közegészségügyét és nemzetközi kapcsolatait fenyegető veszélyeket". A (8) bekezdés alapján a határellenőrzés nemcsak a határátkelőhelyeken történő, személyekre vonatkozó ellenőrzéseket és a határátkelőhelyek közötti határőrizetet jelenti, hanem a belső biztonsággal kapcsolatos kockázatok, valamint a külső határok biztonságával kapcsolatos lehetséges veszélyek elemzését is.

Azt is kimondja a rendelet (22) bekezdése, hogy egy vagy több tagállam közrendjét vagy belső biztonságát komolyan veszélyeztető helyzetekben, ezért kivételes körülmények között lehetővé kell tenni a belső határokon történő határellenőrzés ideiglenes visszaállítását. ${ }^{53}$

A beutazási feltétel (többek között) az, hogy a beutazók nem jelentenek veszélyt a tagállamok közrendjére, belső biztonságára, közegészségügyére vagy nemzetközi kapcsolataira, különösen nem állnak a tagállamok nemzeti adatbázisaiban szereplő ugyanezen okok miatt beutazási tilalmat elrendelő figyelmeztető jelzés hatálya alatt. ${ }^{54}$

A szabad mozgás uniós jogával rendelkező személyek úgynevezett minimum-ellenőrzése ${ }^{55}$ keretében a határőrök „szúrópróbaszerüen lekérdezhetnek adatokat nemzeti és európai adatbázisokból annak érdekében, hogy megállapítsák, hogy a belépni szándékozó nem jelent-e valós, közvetlen és kellően komoly veszélyt a tagállamok belső biztonságára, közrendjére vagy nemzetközi kapcsolataira, illetve veszélyt a közegészségügyre".

A harmadik országbelieket be- és kiutazáskor alapos ellenőrzéseknek szükséges alávetni, amelynek keretében vizsgálni kell, hogy „az érintett harmadik országbeli állampolgár, a járműve és a birtokában lévő tárgyak nem jelentenek-e veszélyt valamely tagállam közrendjére, belső biztonságára, közegészségügyére vagy nemzetközi kapcsolataira". ${ }^{56}$

A „,belső biztonsággal kapcsolatos kockázatok” kifejezés a rendeletben tizenhárom alkalommal szerepel. Ennél is többször, mintegy húsz alkalommal található meg a „belső biztonságot fenyegető komoly veszély”, vagy a tagállam „belső biztonságát komolyan

$52 \quad$ Az Európai Parlament és a Tanács (EU) 2019/1155 rendelete (2019. június 20.). A rendelet 2020. február 2-től hatályos.

53 Az ilyen intézkedések ideiglenes visszaállításának hatályát és időtartamát a közrendet vagy a belső biztonságot fenyegető komoly veszély elhárításához feltétlenül szükséges mértékre kell korlátozni. A belső határokon történő határellenőrzés visszaállítása kivételesen szükségessé válhat a belső határellenőrzések nélküli térség szintjén vagy nemzeti szinten a közrendet vagy a belső biztonságot fenyegető komoly veszély esetén, különösen terrortámadásokat vagy-fenyegetéseket követően, vagy a szervezett bünözés miatti veszély esetén. A migráció vagy az, ha harmadik országok állampolgárai nagy számban lépik át a külső határokat, e rendelet szerint önmagában nem tekintendő a közrendet vagy a belső biztonságot fenyegető veszélynek. Schengeni határellenőrzési kódex 6. cikk (1) bek. e) pontja.

Schengeni határellenőrzési kódex 8. cikk (2) bek.

Schengeni határellenőrzési kódex (3) bek. 
veszélyeztető helyzet” szókapcsolat. Néhány helyen a komoly jelzőt mellőzve a „belső biztonságot fenyegető veszély" jelenik meg a rendeletben, míg elvétve további feltételek állnak fenn: a szabad mozgás jogával rendelkezők esetében a „valós, közvetlen és kellően komoly veszély a tagállamok belső biztonságára” fordulat szerepel a kódexben. Ezt a magyar jogszabályok is lényegében átültették, hiszen a vonatkozó magyar törvény szerint a szabad mozgás és beutazás jogát korlátozni csak abban az esetben lehet, ha a külföldi „valódi, közvetlen és súlyos veszélyt jelent a nemzetbiztonságra”.

A két kódexben számos helyen szerepel a (nemzet)biztonság veszélyeztetése, az egyes rendeleteken belül következetesen, de a két jogszabályban néhol eltérően. A határellenőrzési kódex több jelzőt is társított, a fokozatokat is érzékeltetve. A Vízumkódex két helyen kereszthivatkozásként utalt vissza a határellenőrzési kódexre.

\section{4. Összefoglalás és következtetések}

A migrációs jogszabályokban többféleképpen is megjelenik a nemzetbiztonság veszélyeztetése:

1. táblázat

Áttekintő táblázat a nemzetbiztonság veszélyeztetésének magyar migrációs joganyagban történő megjelenéséröl

\begin{tabular}{|c|c|c|}
\hline Tárgy & Keretszöveg & $\begin{array}{c}\text { A veszélyeztetés kifejezése } \\
\text { vagy foka }\end{array}$ \\
\hline menekültkénti elismerés & $\begin{array}{l}\text { nem lehet elismerni azt a külföldit, akinek } \\
\text { Magyarország területén való tartózkodása... }\end{array}$ & $\begin{array}{l}\text { a nemzetbiztonságot } \\
\text { veszélyezteti }\end{array}$ \\
\hline oltalmazottkénti elismerés & $\begin{array}{l}\text { nem lehet elismerni azt a külföldit, akinek } \\
\text { Magyarország területén való tartózkodása... }\end{array}$ & $\begin{array}{l}\text { a nemzetbiztonságot } \\
\text { veszélyezteti }\end{array}$ \\
\hline menedékeskénti elismerés & $\begin{array}{l}\text { nem lehet elismerni azt a külföldit, akinek... } \\
\text { Magyarország területén való tartózkodása... }\end{array}$ & $\begin{array}{l}\text { nemzetbiztonsági érdeket } \\
\text { sért }\end{array}$ \\
\hline $\begin{array}{l}\text { menekült részére } \\
\text { személyazonosító igazolvány, } \\
\text { kétnyelvű úti okmány }\end{array}$ & jogosult, ha... & $\begin{array}{l}\text { nemzetbiztonsági érdek } \\
\text { nem zárja ki }\end{array}$ \\
\hline $\begin{array}{l}\text { az oltalmazott a jogszabályban } \\
\text { meghatározott úti okmányra } \\
\text { jogosult }\end{array}$ & az úti okmány kiállítása... & $\begin{array}{l}\text { nemzetbiztonsági érdekből } \\
\text { megtagadható }\end{array}$ \\
\hline menekültügyi őrizet & $\begin{array}{l}\text { a menekültstátuszt kérelmezőt a hatóság } \\
\text { őrizetbe veheti, amennyiben ... szükséges. }\end{array}$ & $\begin{array}{l}\text { a nemzetbiztonság védelme } \\
\text { érdekében }\end{array}$ \\
\hline $\begin{array}{l}\text { menekültügyi eljárás gyorsított } \\
\text { eljárás }\end{array}$ & $\begin{array}{l}\text { ban is lefolytatható, amennyiben } \\
\text { a kérelmező... }\end{array}$ & $\begin{array}{l}\text { súlyos okból veszélyt } \\
\text { jelenthet Magyarország } \\
\text { nemzetbiztonságára }\end{array}$ \\
\hline $\begin{array}{l}\text { szabad mozgás (beutazás) } \\
\text { és tartózkodás korlátozása }\end{array}$ & $\begin{array}{l}\text { arányosság elvén, az érintett kizárólag olyan } \\
\text { személyes magatartása alapján... }\end{array}$ & $\begin{array}{l}\text { valódi, közvetlen } \\
\text { és súlyos veszélyt jelent } \\
\text { a nemzetbiztonságra }\end{array}$ \\
\hline $\begin{array}{l}\text { idegenrendészeti hatóság } \\
\text { kiutasíthatja }\end{array}$ & $\begin{array}{l}\text { az EGT-állampolgárt vagy azt a családtagot, } \\
\text { akinek beutazása vagy tartózkodása... }\end{array}$ & $\begin{array}{l}\text { valódi, közvetlen } \\
\text { és súlyos veszélyt } \\
\text { jelent Magyarország } \\
\text { nemzetbiztonságára }\end{array}$ \\
\hline
\end{tabular}




\begin{tabular}{|c|c|c|}
\hline Tárgy & Keretszöveg & $\begin{array}{c}\text { A veszélyeztetés kifejezése } \\
\text { vagy foka }\end{array}$ \\
\hline $\begin{array}{l}\text { vízumkonzultáció - } \\
\text { felhatalmazás, hogy } \\
\text { rendeletben állapítsák meg }\end{array}$ & $\begin{array}{l}\text { más schengeni állam vízumkiadó hatósága } \\
\text { a kilencven napot meg nem haladó } \\
\text { vízum kiadását megelőzően a központi } \\
\text { vízumhatósággal egyeztet... }\end{array}$ & $\begin{array}{l}\text { a nemzetbiztonság védelme } \\
\text { érdekében }\end{array}$ \\
\hline $\begin{array}{l}\text { harmadik országbeli } \\
\text { állampolgár vállalaton belüli } \\
\text { áthelyezése - külön engedély } \\
\text { nélkül munkát végezhet } \\
\text { Magyarországon } \\
\end{array}$ & $\begin{array}{l}\text { az EU másik tagállama által kiadott érvényes } \\
\text { tartózkodási engedéllyel és érvényes úti } \\
\text { okmánnyal rendelkezik és amennyiben } \\
\text { a beutazása vagy tartózkodása... }\end{array}$ & $\begin{array}{l}\text { Magyarország } \\
\text { nemzetbiztonságát nem } \\
\text { sérti }\end{array}$ \\
\hline $\begin{array}{l}\text { harmadik országbeli külföldi } \\
\text { kilencven napot meg nem } \\
\text { haladó tartózkodásra jogosító } \\
\text { vízum }\end{array}$ & $\begin{array}{l}\text { meghatározott esetekben csak a központi } \\
\text { vízumhatóság hozzájárulásával adható ki... }\end{array}$ & $\begin{array}{l}\text { a nemzetbiztonság védelme } \\
\text { érdekében }\end{array}$ \\
\hline $\begin{array}{l}\text { felhatalmazás (több } \\
\text { miniszternek) rendeletben } \\
\text { megállapítani azokat } \\
\text { az eseteket }\end{array}$ & $\begin{array}{l}\text { a kilencven napot meg nem haladó } \\
\text { vízum csak a központi vízumhatóság } \\
\text { hozzájárulásával adható ki, és más schengeni } \\
\text { állam vízumkiadó hatósága a kiadást } \\
\text { megelőzően a központi vízumhatósággal } \\
\text { egyeztet... }\end{array}$ & $\begin{array}{l}\text { a nemzetbiztonság védelme } \\
\text { érdekében }\end{array}$ \\
\hline $\begin{array}{l}\text { 29/2010. (V. 12.) IRM-KüM- } \\
\text { PTNM együttes rendelet } \\
\text { a három hónapot meg nem } \\
\text { haladó tartózkodásra jogosító } \\
\text { vízum kiadását megelőző } \\
\text { kötelező egyeztetés eseteiről }\end{array}$ & $\begin{array}{l}\text { a konzuli tisztviselő a központi vízumhatóság } \\
\text { hozzájárulását kéri, ha a vízumkérelmének } \\
\text { elbírálása a ... különös körültekintést igényel }\end{array}$ & $\begin{array}{l}\text { a nemzetbiztonság védelme } \\
\text { érdekében }\end{array}$ \\
\hline $\begin{array}{l}\text { harmadik országbeliek } \\
\text { kilencven napot meghaladó } \\
\text { tartózkodás általános szabályai }\end{array}$ & ha a külföldi beutazása vagy tartózkodása... & $\begin{array}{l}\text { nem veszélyezteti } \\
\text { Magyarország } \\
\text { nemzetbiztonságát }\end{array}$ \\
\hline $\begin{array}{l}\text { harmadik } \\
\text { országbeliek - nemzeti vízum }\end{array}$ & $\begin{array}{l}\text { nemzeti vízum kérelemről meghatározott } \\
\text { esetekben az AH és a TEK véleményét kéri... }\end{array}$ & $\begin{array}{l}\text { a nemzetbiztonság védelme } \\
\text { érdekében }\end{array}$ \\
\hline $\begin{array}{l}\text { harmadik országbeliek - } \\
\text { tartózkodásiengedély-kérelem }\end{array}$ & $\begin{array}{l}\text { OIF regionális igazgatósága a kérelemről } \\
\text { meghatározott esetekben az AH, a TEK } \\
\text { és a rendőrség véleményét kéri... }\end{array}$ & $\begin{array}{l}\text { a nemzetbiztonság védelme } \\
\text { érdekében }\end{array}$ \\
\hline $\begin{array}{l}\text { tanulmányi célú - hallgatói } \\
\text { mobilitási tartózkodási } \\
\text { engedély }\end{array}$ & az OIF az engedély kiadását megtagadja & $\begin{array}{l}\text { Magyarország } \\
\text { nemzetbiztonságát } \\
\text { veszélyezteti }\end{array}$ \\
\hline $\begin{array}{l}\text { kutatási célú tartózkodási } \\
\text { engedély - kutatói rövid távú } \\
\text { mobilitási igazolás kiadása }\end{array}$ & $\begin{array}{l}\text { OIF kifogást emel, ha a kutató (vagy } \\
\text { családtagja) tartózkodása... }\end{array}$ & $\begin{array}{l}\text { Magyarország } \\
\text { nemzetbiztonságát } \\
\text { veszélyezteti }\end{array}$ \\
\hline $\begin{array}{l}\text { a kutatói hosszú távú } \\
\text { mobilitási tartózkodási } \\
\text { engedély }\end{array}$ & $\begin{array}{l}\text { az OIF a kiállítását megtagadja (vagy } \\
\text { visszavonja), ha a kutató (vagy családtagja)... }\end{array}$ & $\begin{array}{l}\text { Magyarország } \\
\text { nemzetbiztonságát } \\
\text { veszélyezteti }\end{array}$ \\
\hline letelepedés & $\begin{array}{l}\text { nem kaphat ideiglenes, nemzeti vagy EK } \\
\text { letelepedési engedélyt az a harmadik } \\
\text { országbeli, akinek a letelepedése... }\end{array}$ & $\begin{array}{l}\text { veszélyezteti Magyarország } \\
\text { nemzetbiztonságát }\end{array}$ \\
\hline $\begin{array}{l}\text { harmadik } \\
\text { országbeliek - kiutasítás } \\
\text { és önkéntes távozás }\end{array}$ & $\begin{array}{l}\text { nem kell határidőt meghatározni, vagy OIF } \\
\text { hetedik napnál korábbi napra... }\end{array}$ & $\begin{array}{l}\text { magyarországi } \\
\text { tartózkodása veszélyezteti } \\
\text { a nemzetbiztonságot }\end{array}$ \\
\hline
\end{tabular}




\begin{tabular}{|c|c|c|}
\hline Tárgy & Keretszöveg & $\begin{array}{c}\text { A veszélyeztetés kifejezése } \\
\text { vagy foka }\end{array}$ \\
\hline $\begin{array}{l}\text { Magyarország területén } \\
\text { történő légi átszállításhoz } \\
\text { történő hozzájárulás }\end{array}$ & $\begin{array}{l}\text { az OIF megtagadhatja, ill. visszavonhatja, ha } \\
\text { a külföldi átszállítása... }\end{array}$ & $\begin{array}{l}\text { veszélyezteti Magyarország } \\
\text { nemzetbiztonságát }\end{array}$ \\
\hline $\begin{array}{l}\text { idegenrendészeti kiutasítás } \\
\text { és önálló beutazási } \\
\text { és tartózkodási tilalom } \\
\text { (harmadik országbeliek) }\end{array}$ & $\begin{array}{l}\text { idegenrendészeti hatóság önálló BTT-t } \\
\text { rendel el ismeretlen helyen vagy külföldön } \\
\text { tartózkodó harmadik országbelivel szemben, } \\
\text { akinek a beutazása és a tartózkodása... }\end{array}$ & $\begin{array}{l}\text { a nemzetbiztonságot sérti } \\
\text { vagy veszélyezteti }\end{array}$ \\
\hline idegenrendészeti kiutasítás & $\begin{array}{l}\text { idegenrendészeti hatóság t rendel el } \\
\text { a harmadik országbelivel szemben, akinek } \\
\text { a beutazása és tartózkodása... }\end{array}$ & $\begin{array}{l}\text { a nemzetbiztonságot sérti } \\
\text { vagy veszélyezteti }\end{array}$ \\
\hline $\begin{array}{l}\text { harmadik országbeliek } \\
\text { házassági vagy családi } \\
\text { életközösségben }\end{array}$ & $\begin{array}{l}\text { harmadik országbeli (bevándoroltként } \\
\text { vagy letelepedettként tartózkodik } \\
\text { Magyarországon), bevándorolt vagy } \\
\text { letelepedett harmadik országbeliekkel } \\
\text { házassági vagy családi életközösségben él, } \\
\text { és tartózkodási engedéllyel rendelkezik, csak } \\
\text { akkor utasítható ki, ha további tartózkodása... }\end{array}$ & $\begin{array}{l}\text { a nemzetbiztonságot } \\
\text { súlyosan sérti }\end{array}$ \\
\hline $\begin{array}{l}\text { emberkereskedelem } \\
\text { áldozatainak kiutasítása }\end{array}$ & $\begin{array}{l}\text { emberkereskedelem áldozatává vált } \\
\text { harmadik országbelit a számára biztosított } \\
\text { gondolkodási idő alatt csak akkor lehet } \\
\text { kiutasítani, ha... }\end{array}$ & nemzetbiztonságot sérti \\
\hline $\begin{array}{l}\text { Más EU-tagállamban } \\
\text { jogszerűen tartózkodó } \\
\text { (kiutasítása Magyarországról) }\end{array}$ & $\begin{array}{l}\text { harmadik országbeli állampolgár csak akkor } \\
\text { utasítható ki, ha... }\end{array}$ & nemzetbiztonságot sérti \\
\hline $\begin{array}{l}\text { idegenrendészeti hatóság } \\
\text { beutazási és tartózkodási } \\
\text { tilalmat rendelhet el }\end{array}$ & $\begin{array}{l}\text { harmadik országbeli személyes } \\
\text { körülményeire, ismételt beutazásának } \\
\text { és tartózkodásának... }\end{array}$ & $\begin{array}{l}\text { a nemzetbiztonságra } \\
\text { jelentett veszélyére } \\
\text { (figyelemmel) }\end{array}$ \\
\hline $\begin{array}{l}\text { a beutazási és tartózkodási } \\
\text { tilalom legfeljebb tíz évre } \\
\text { rendelhető el, ha }\end{array}$ & $\begin{array}{l}\text { a harmadik országbeli állampolgár } \\
\text { tartózkodása Magyarország területén... }\end{array}$ & $\begin{array}{l}\text { nemzetbiztonságot } \\
\text { jelentősen veszélyeztetné }\end{array}$ \\
\hline kitoloncolás & $\begin{array}{l}\text { visszairányítást vagy a kiutasítást hatósági } \\
\text { kísérettel (kitoloncolás) kell végrehajtani, ha } \\
\text { a külföldi kiutazásának ellenőrzése... }\end{array}$ & $\begin{array}{l}\text { nemzetbiztonság érdekében } \\
\text { (szükséges) }\end{array}$ \\
\hline hontalanság & $\begin{array}{l}\text { kérelmet határozattal el kell utasítani, } \\
\text { amennyiben a kérelmező tartózkodása... }\end{array}$ & $\begin{array}{l}\text { sérti vagy veszélyezteti } \\
\text { Magyarország } \\
\text { nemzetbiztonságát }\end{array}$ \\
\hline $\begin{array}{l}\text { tartózkodásiengedély- } \\
\text { kérelmek számának } \\
\text { korlátozása }\end{array}$ & $\begin{array}{l}\text { jövedelemszerzési, munkavállalási } \\
\text { vagy egyéb célú tartózkodási engedély } \\
\text { jövőbeni benyújtását adott ország(ok) } \\
\text { állampolgárainak vonatkozásában } \\
\text { rendeletben korlátozza, ha azok létszáma } \\
\text { Magyarország számára... }\end{array}$ & $\begin{array}{l}\text { nemzetbiztonsági } \\
\text { kockázatot jelenthet }\end{array}$ \\
\hline honosítás & $\begin{array}{l}\text { kérelmére honosítható a nem magyar } \\
\text { állampolgár, ha honosítása... }\end{array}$ & $\begin{array}{l}\text { Magyarország } \\
\text { nemzetbiztonságát nem } \\
\text { sérti }\end{array}$ \\
\hline
\end{tabular}


A nemzetbiztonság védelme érdekében kifejezés az egyik leginkább használt feltétel, nyolc alkalommal szerepel. A nemzetbiztonság érdekében fordulat is megjelenik egyszer. Szintén előfordul az, hogy nemzetbiztonsági érdek nem zárja ki, vagy nemzetbiztonsági érdekből megtagadható, vagy a nemzetbiztonságot sérti vagy veszélyezteti szókapcsolat a táblázat alapján kétszer jelenik meg.

Két helyen találjuk meg a Magyarország nemzetbiztonságát nem sérti fordulatot: következő két formában: nemzetbiztonságot sérti. Egy alkalommal az alábbi formula használt: nemzetbiztonsági érdeket sért.

A nemzetbiztonságot veszélyezteti ezen alakban háromszor, míg a Magyarország nemzetbiztonságát veszélyezteti, vagy a nem veszélyezteti Magyarország nemzetbiztonságát szókapcsolat négy alkalommal szerepel. Egy helyen az alábbi szófordulatot találjuk: a magyarországi tartózkodása veszélyezteti a nemzetbiztonságot. Látható, az egyik legtöbb alkalommal a veszélyeztetéssel mint jogszabályi feltétellel találkozhatunk a migrációs joganyag vonatkozó részében. Érdekes és különös, hogy a nemzetbiztonsági kockázatot jelenthet kifejezés bár elfogadott szakszó, csupán egy alkalommal jelenik meg a migrációs joganyagban.

Ami a fokozatokat, jelzőket illeti, fokozatosságot mutat, hogy egyes esetekben nem elegendő a veszélyeztetést előre jelezni és valószínúsíteni, hanem ennél közelebbi és komolyabb veszélyeztető tényezőre kell információt gyűjteni: beutazási és tartózkodási tilalom harmadik országbeliek esetén (legfeljebb) tíz évre is elrendelhető nemzetbiztonsági okokból, abban az esetben, ha a külföldi magyarországi tartózkodása a nemzetbiztonságot jelentősen veszélyeztetné.

Szintén egy „erősebb” fokozatot jelent: menekültügyi eljárás gyorsított eljárásban is lefolytatható, ha a kérelmezó súlyos okból veszélyt jelenthet Magyarország nemzetbiztonságára. Ennél is hangsúlyosabban szúkítette a törvényalkotó a szolgálatok mozgásterét, amikor az alábbi kifejezést emelte be az Szmtv.-be: valódi, közvetlen és súlyos veszélyt jelent a nemzetbiztonságra, vagy valódi, közvetlen és súlyos veszélyt jelent Magyarország nemzetbiztonságára. Értelmezhető a legszigorúbb feltételként a szolgálatok számára a nemzetbiztonságot súlyosan sérti kifejezés.

Megállapítottam, hogy a vizsgált jogszabályok alapján a nemzetbiztonság veszélyeztetésének megjelenése a migrációs joganyagban nem egységes. A fokozatok és jelzők alkalmazása nyelvileg és nemzetbiztonsági szakmai szempontokkal is indokolható. A legalább tízféle kifejezés helyett ugyanakkor célszerű lenne egy 3-5 lépcsős skála bevezetése.

Egy lehetséges fokozatrendszer a következő (a távoli, potenciális kockázatoktól a legsúlyosabb, bekövetkező sérelemig):

1. nemzetbiztonsági kockázatot vet fel,

2. veszélyezteti a nemzetbiztonságot, vagy veszélyezteti Magyarország nemzetbiztonságát,

3. súlyosan veszélyezteti a nemzetbiztonságot, vagy Magyarország nemzetbiztonságát,

4. sérti a nemzetbiztonságot, vagy sérti Magyarország nemzetbiztonsági érdekeit. 
A fentiekhez könnyebben alkalmazkodnának a jogalkalmazó idegenrendészeti hatóságok, nemzetbiztonsági szolgálatok, a terrorelhárításért felelős szerv, a bíróság és az ügyfelek egyaránt.

\section{Felhasznált irodalom}

Balla Zoltán: A rendészet alapjai és egyes ágazatai. Budapest, Dialóg Campus, 2017. Balla Zoltán: A rendészet fogalma és rendszere, a nemzetbiztonsági igazgatás. In Korinek László (szerk.): Értekezések a rendészetről. Budapest, Nemzeti Közszolgálati Egyetem Rendészettudományi Kar, 2014. 17-51.

Finszter Géza: Rendészettan. Budapest, Dialóg Campus, 2018.

Hautzinger Zoltán: A nemzetbiztonsági érdek megjelenése a migrációban és az idegenjogban. In Dobák Imre - Hautzinger Zoltán (szerk.): Szakmaiság szerénység, szorgalom. Ünnepi kötet a 65 éves Boda József tiszteletére. Budapest, Dialóg Campus, 2018. 265-280.

Hautzinger Zoltán: Szemelvények a migráció szabályozásáról. Pécs, AddAnn, 2016. Menekültügyi ismeretek. Tansegédlet, Budapest, Országos Idegenrendészeti Főigazgatóság, 2019. augusztus. Elérhető: https://cmsadmin-pub.uni-nke.hu/document/rtkuni-nke-hu/menekultugy_ism_tansegedlet.pdf (A letöltés dátuma: 2020. 09. 25.)

Wetzel Tamás: A bevándorlás kérdése Magyarországon. Budapest, Publikon, 2011. Windt Szandra: Külföldiek rendészete, bevándorlás és menekültügy. In Korinek László (szerk.): Értekezések a rendészetről. Budapest, Nemzeti Közszolgálati Egyetem Rendészettudományi Kar, 2014. 291-307.

\section{Ajánlott irodalom}

Szép Árpád: Menekültügy a gyakorlatban. In Klenner Zoltán (szerk.): Menekültügyi ismeretek. Budapest, Dialóg Campus, 2019. 73-173. 